\title{
EDIFICIO BEATRIZ, MADRID. ELEUTERIO POBLACIÓN KNAPPE. LA PIEL DURA Eduardo Delgado Orusco
}

Edificio Beatriz, Madrid

Beatriz Building, Madrid

Eleuterio Población Knappe

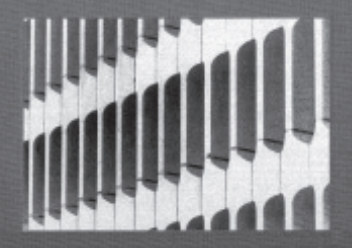

Madrid: Lampreave, 2013

431 pág. Prólogo de Gerardo Ayala Hernández

ISBN: 978-84-616-4914-3

Boletín Académico. Revista de investigación y arquitectura contemporánea

Escuela Técnica Superior de Arquitectura. Universidade da Coruña

elSSN 2173-6723

unw.boletinacademico.com

Número 4 (2014)

Páginas 111-112

Fecha de recepción: 04.02.2014

Fecha de aceptación: 06.02.2014

https://doi.org/10.17979/bac.2014.4.0.1019

No cabe duda de que 2013 será un año que Eduardo Delgado Orusco recordará durante mucho tiempo. Resulta verdaderamente impresionante la actividad editorial que ha desplegado durante los últimos meses. Primero fue el librito «Alvar Aalto en España»; luego «iBendita vanguardia! Arquitectura religiosa en España 1950-1975», reedición revisada y aumentada de «Entre el cielo y el suelo» (2006), derivado de su tesis doctoral; siguió «Paisajes con alma. Inventario de lugares para rezar», donde explica su propia obra de temática religiosa; después «Imagen y memoria. Fondos del archivo fotográfico del Instituto Nacional de Colonización 1939-1973»; y ahora la monografía «Edificio Beatriz, Madrid. Eleuterio Población Knappe. La piel dura». Este último libro documenta y estudia un edificio importante que, como el mismo autor explica, apenas mereció la atención de la crítica en el momento de su construcción. Y esto a pesar de sus evidentes valores urbanos, plásticos y tecnológicos.

El Edificio Beatriz (Madrid, 1964/75) fue construido por Eleuterio Población Knappe - arquitecto fascinado por la seriación modular que cualquier crítico cinematográfico definiría como un buen artesano - como sede central del Banco Popular Español. El solar, ubicado en pleno barrio de Salamanca, estaba ocupado por el convento de monjas Jerónimas que había sido fundado por la preceptora de los hijos de los Reyes Católicos, Beatriz Galindo, la Latina, a quien el edificio rinde homenaje.

Tipológicamente, Población sigue la línea marcada por Gordon Bunshaft/SOM en la Banca Lambert de Bruselas (1958/65), otro edificio de "piel dura" realizado con exquisitos prefabricados de hormigón; y desde un punto de vista institucional, responde al gusto del promotor por una arquitectura sobria pero de calidad, destinada a durar muchos años (o como decía Sota, de hacer un lugar en el que, sencillamente, uno se sienta mejor).

El libro forma parte del plan estratégico para la valorización, difusión y rehabilitación integral del edificio, encargado al propio despacho del autor, Reset Arquitectura. Delgado Orusco aprovecha la ocasión para acceder a unos archivos inéditos y apenas transitados por la crítica, realizando una revisión completa de los inmuebles utilizados o encargados por el Banco Popular, desde sus orígenes hasta nuestros días. 
La información se estructura en cuatro apartados: «Historia, conceptualización y desarrollo del Edificio Beatriz», la más extensa y que tal vez ganaría en claridad con otro tipo de estructura; "Proyecto y construcción», donde el edificio se documenta en detalle, con los planos originales, los informes técnicos del Instituto Torroja y el facsímil de la separata que la revista Informes de la Construcción le dedicó en su momento; $\mathrm{y}$ "Cuarenta años después», donde el autor y sus asesores plasman sus recuerdos sobre el momento de construcción del Beatriz, y el propio Delgado repasa las actuaciones recientes realizadas en él.

Dos espléndidos reportajes fotográficos, firmados por David Jiménez y Miguel de Guzmán, completan este cuidado volumen, editado por Lampreave con todo lujo de detalles y que constituye una fuente de información de gran interés para revisitar un momento no siempre bien explicado de nuestra historia reciente.

\section{Esteban Fernández-Cobián}

